BAHTERA: Jurnal Pendidikan Bahasa dan Sastra, Volume 18 Nomor 2 Juli 2019 http://journal.unj.ac.id/unj/index.php/bahtera/

P-ISSN : 0853-2710

E-ISSN : 2540-8968

\title{
CROSS-CULTURAL COMMUNICATION: JAVANESE AND SUNDANESE VOCABULARIES THE SAME IN FORM AND DIFFERENT IN MEANING
}

\author{
Dira Hildayani \\ Language Center for Development and Preservation \\ dirahildayani@gmail.com
}

\begin{abstract}
This study discusses the vocabulary of Sundanese which has similar in forms and different in meanings to the Javanese vocabulary. The purpose of this study is to find out (1) words in Sundanese which form is the same as the word in Javanese but different in meanings and (2) words in Sundanese which lexical form and meaning are the same as words in Javanese but they're in a different variety (familiar variety or respect/high variety). The method used is the matching method (Sudaryanto, 1996). The findings of this study indicate that some words in Sundanese have the same form but different meanings with Javanese, such as the word 'tea' as a personal pronoun or particle in Sundanese but means 'tea' as a drink in Javanese. Some words in Sundanese also indicate that a word that is considered to be a variety of respect, is considered a familiar variety in Javanese, such as the word 'Wengi' in Sundanese and Javanese which means 'night'. In Sundanese, the word 'wengi' is a variety of respectful languages, while in Javanese 'wengi 'it is a familiar variety. This study reveals the linguistic phenomena of most language speakers in heterogeneous societies, namely Sundanese and Javanese and both have many vocabularies with the same form but have different in meaning.
\end{abstract}

Keywords: communication, cross-cultural, Sundanese-Javanese vocabularies

\section{INTRODUCTION}

Humans are creatures that cannot be separated from interacting with one another. In interacting, customs, ethics, science, and culture are closely related, so it is not easy to adjust the differences that occur in interaction, especially in communication. In communicating, language is an effective communication tool. The language and variety of languages used are different. Daily communication will certainly be different when in school or in the community. In communication, we may use regional languages, while communicating in the teaching and learning process must use formal language so that it can be understood by our interlocutors, who are generally heterogeneous communities.

At time Indonesian is used as the language of communication between ethnicities, problems will appear that are related with understanding language through the vocabulary used. There are those who include their local language vocabulary or terms in communicating both with their fellow ethnic groups and 
BAHTERA: Jurnal Pendidikan Bahasa dan Sastra, Volume 18 Nomor 2 Juli 2019 http://journal.unj.ac.id/unj/index.php/bahtera/

P-ISSN : 0853-2710

E-ISSN : 2540-8968

JRNAL PENDIDIKAN BAHASA DAN SASTRA

other ethnic groups, and some never use it at all. Someone who uses Indonesian intentionally recites the Javanese vocabulary to designate a particular word so that it can be seen that someone is a part of Javanese society without the person mentioning their origin or cultural identity. However, if this happens among Sundanese and Javanese speakers, there is a possibility of misunderstanding. That is because in both languages there are words that have the same form but different meanings, for examples the words atos and sangu. In Sundanese the word atos means sudah while in Javanese, the word atos means keras. In Sundanese, the word sangu means nasi, while in Javanese, the word sangu means stock. In addition, in both languages there are words with the same form, the lexical meaning is the same, but the usage is in different languages, for examples the words rambut and wengi. In both Sundanese and Javanese, the word rambut means the same lexical meaning, namely rambut. However, in Sundanese the word rambut is used in a variety of respect/high, as in Javanese, the word rambut is used in a familiar manner.

In Sundanese, the concept of rambut variety is familiar to use the word buuk, whereas in Javanese for the concept of rambut variety of respect/high is used the word rikma. Both in Sundanese and Javanese, the word wengi means the same lexical meaning, namely malam. However, in Sundanese the word wengi is used in a variety of respect/high, as in Javanese, the word wengi is used in a familiar manner. In Sundanese, the concept of malam variety is used as the word peuting, while in Javanese the

concept of malam, variety of respect/high is used the word dalu.

This research is limited to Sundanese words that are in the same form as Javanese words but different meanings and Sundanese words which lexical forms and meanings are the same as words in Javanese but different uses. It aims to find out (1) words in Sundanese which form is the same as words in Javanese but different meanings and (2) words in Sundanese which lexical forms and meanings are the same as words in Javanese but are used in different various ways (familiar variety or respect/high variety).

Speakers of Sundanese and Javanese can communicate carefully using language that does not cause misunderstanding when meeting friends who speak from Java and vice versa. This research is about a different study from the research conducted by several researchers, among others, namely 'Contrastive Analysis of Indonesian and Malaysian Vocabulary on Upin Ipin Animated Film' written by Risa Mustafariha. The other research is talking about 'Comparison of Indonesian and Pattani Malay in Thailand', written by Miss Rosmini Che-Uma. This study discusses Javanese - Sundanese vocabularies which are the same form and different in meaning.

In semantics, the meaning of sense is distinguished by meaning (meaning). According to Djajasudarma (1999:5), meaning is the linkage that exists between the elements of the language itself (especially words) while meaning is the understanding of a word as an element connected. Lyons (1977:204) argues that assessed the 
meaning of a word is understanding the study of the word relating to the relationships of meaning that make the word different from other words.

Every language has its own system. One language has a different system than other languages. Even so, it does not rule out the possibility of similarities and similarities that can be found by comparing two or more languages. Language analysis can be done diachronically and synchronously. The first is called comparative historical analysis, while the second is called descriptive analysis. Descriptive analysis that compares two or more languages is usually called comparative analysis (Robins, 1994).

Contrastive analysis refers to similarities and differences between two or more languages. Contrastive analysis is a method of comparative language as explained by Oleg Buren (in Allen \& Corder, 1974:280) that 'contrastive analysis should convey as many insights as possible into the differences or similarities between the language compared'.

In the contrastive analysis, the lexical form is an important basis for the use of language that is similar because the lexicon is the meat for grammar or grammar as a language framework (Kridalaksana, 1988). The lexicon has structures such as synonyms, homonyms, antonyms, and polysemy. In addition, lexical studies are also related to semantic studies, which are called lexical semantics (Lyons, 1987), as opposed to grammatical semantics.

\section{METHODS}

The data analysis technique uses the equivalent method. The determinant is the fact designated by language (referent), other languages, and speech partners. The naming of the matching method along with this determinant follows (Sudaryanto, 1993). The equivalent method is out of designator, detached and not part of the language (langue). Matching method is divided into several types based on the determinant. In this analysis phase, the researcher uses a matching method whose determinant is referent (referential equivalent method) and speech partner (pragmatic equivalent method). The referential equivalent method is a method in which the determinant is a reality designated by language or referent. In each speech, there are several elements that become important roles, including speakers, listeners, places of speech, subject matter, the atmosphere of speech, and so on. In conversation, a speaker always considers who he is talking to, where, about what, when and in what condition. With these considerations there will be a variety of language uses according to their functions and situations (Suwito, 1990).

The statement was supported by Agustina who said that there are seven dimensions which are sociolinguistic problems, namely the social identity of speakers, the social identity of listeners involved in the communication process, the social environment in which events occur, synchronous and diachronic analysis of social dialects, assessment social differences by speakers of the behavior of speech forms, levels of variation and variety of linguistics, and 
BAHTERA: Jurnal Pendidikan Bahasa dan Sastra, Volume 18 Nomor 2 Juli 2019 http://journal.unj.ac.id/unj/index.php/bahtera/

P-ISSN : 0853-2710

E-ISSN : 2540-8968

BAHTERA

JURNAL PENDIDIKAN BAHASA DAN SASTRA

practical application of sociolinguistic research (Agustina, 2010). According to (Kramsch, 2014), a marker of cultural identity is seen when someone inserts certain words that are unique and only understood by a particular society. The action of someone mixing different vocabulary is done as a step to show one's cultural identity.

Several studies related to crosscultural communication, first, CrossCultural Communication in Maintaining Harmony between Religious People in Jaton Minahasa Village (Paramita \& Sari, 2016). This research is about crosscultural communication like what happened between residents in Jaton Village and the majority of citizens who are of different religions. Samovar, Porter \& McDaniel (2010) in (Paramita \& Sari, 2016) explained that culture consists of countless elements, there are five important things that are directly related, namely: history, religion, values, social organization, and language. The results of this study indicate that the results that occurred acculturation between citizens who are Muslim and those who are Christian. This acculturation indicates that the interaction formed between the two religious groups is an associative interaction pattern, so there is no conflict like in some other regions.

Second, Intercultural and Javanese Intercultural Communication Patterns in Yogyakarta (Nugroho, Lestari, \& Wiendijarti, 2012), discuss intercultural communication that occurs namely, in the use of language, perceptions, forms of nonverbal communication, food and social interaction, but both are able to interpret and understand different forms of culture.

The results of this study indicate that different cultural patterns between Batak tribes' students at UPN "Veteran" Yogyakarta and Yogyakarta indigenous people have a Low Context and Masculinity cultural pattern, while the Yogyakarta indigenous people have a High Context and Feminity cultural patterns.

Third, Cross-Cultural Communication of Foreign and Local Residents in Bukit Lawang (Rudianto, Syam, \& Harahap, 2015), shows that different cultures, languages, and daily habits become obstacles in the interaction between citizens and foreign tourists. Thus, the use of language and communication is intensive, both to overcome cultural differences between tourists and local residents.

According to (Wedhawati, 2006), the level of speech is a variety of languages which differences are determined by the attitude of the speaker to the talking partner or the third person discussed. Furthermore, Wedhawati explained that differences in age, social level, and distance of intimacy between the speaker and the speaking partner will determine the variation of the language chosen. Errors in choosing language variations when speaking will lead to irregularities and are considered impolite. Based on the level of speech, Javanese can be divided into three, namely Javanese ngoko $(\mathrm{Ng})$, middle Javanese (Md) and Javanese krama (Kr).

The level of speech ngoko is a variation of language with ngoko morphemes and vocabulary, used for communication with people who are familiar or do not have a sense of reluctance between the speaker and the 
BAHTERA: Jurnal Pendidikan Bahasa dan Sastra, Volume 18 Nomor 2 Juli 2019 http://journal.unj.ac.id/unj/index.php/bahtera/

P-ISSN : 0853-2710

E-ISSN : 2540-8968

talking partner. Krama's level of speech is a variety of languages with morphemes and krama vocabulary, used for communication with people who are not the familiar and social status is higher than the speaker. Intermediate level of communication is a variety of languages with intermediate morphemes and vocabulary, used for communication with talking partners whose social status is lower than the speaker. This level of middle speech shows a polite and reluctant attitude.

According to (Gunardi, 1996), pragmatically Sundanese can be divided into two, namely subtle (respectful) and rude (wanoh) 'smooth' and 'rude'. Variety of respect is used as a fine language, while a rough variety can be interpreted as a familiar variety. This smooth and coarse language has three categories of usage, namely (1) speaker (persona I), (2) friend to talk (persona II), and (3) spoken of (persona III). Sundanese can be said to be situational, language users have the choice of whether to use fine language or abusive language, depending on the situation. Data that support the distribution, among others, the word rumah in Sundanese has a choice: bumi, imah, or rorompok. The rorompok word includes the first personal pronoun (subtle language), so does the earth inclusion persona pronoun II, while the imah word includes a rough vocabulary, is neutral (does not include pronouns).

All of the researches show that different culture and language will not be barriers in as long one another can show their understanding. In other word, understanding one another can make good in interaction and communication.

\section{RESULT}

This research involved native Sundanese speakers and native Javanese speakers. All of them usually speak in their mother tongue with their family and friends which come from the same language. There are two steps in getting the data, namely finding the same words in Sundanese dan Javanese vocabularies and doing an interview to do confirmation about those words.

1) Words with same forms and different meaning

\begin{tabular}{|l|l|}
\hline \multicolumn{1}{|c|}{ Sundanese } & \multicolumn{1}{c|}{ Javanese } \\
\hline bumi 'rumah' & bumi 'bumi' \\
\hline genep 'enam' & genep 'genap, tidak kurang dan tidak lebih, pas' \\
\hline salapan 'sembilan' & salapan 'tiga puluh lima hari' \\
\hline gedang 'pepaya' & gedhang 'pisang' \\
\hline ical 'jual, hilang' & ical 'hilang' \\
\hline alus 'baik' & alus 'halus' \\
\hline
\end{tabular}


BAHTERA: Jurnal Pendidikan Bahasa dan Sastra, Volume 18 Nomor 2 Juli 2019 http://journal.unj.ac.id/unj/index.php/bahtera/

P-ISSN : 0853-2710

E-ISSN : 2540-8968

\begin{tabular}{|l|l|}
\hline cokot 'ambil' & cokot 'gigit' \\
\hline j(um)eneng 'hidup' & j(um)eneng 'berdiri' \\
\hline kasep 'bagus, ganteng' & kasep 'terlambat' \\
\hline lumpat 'lari' & lumpat 'lompat' \\
\hline rayi 'adik' & rai'wajah' \\
\hline tegalan 'tanah lapang' & tegalan 'ladang' \\
\hline $\begin{array}{l}\text { teh 'kakak perempuan, partikel } \\
\text { dalam bahasa Indonesia' }\end{array}$ & $\begin{array}{l}\text { teh 'nama tumbuhan yang pucuknya biasa } \\
\text { dilayukan dan dikeringkan untuk dibuat minuman, } \\
\text { minuman yang salah satu bahannya teh' }\end{array}$ \\
\hline urang 'saya' & urang 'udang' \\
\hline waos 'gigi' & waos 'baca' \\
\hline
\end{tabular}

Javanese and Sundanese are the major regional languages in Indonesia in terms of the number of speakers. Speakers of both languages are millions, while the other regional languages have only thousands of speakers, some even hundreds. Many of the Sundanese and Javanese people met. Communication between Sundanese and Javanese can be in Indonesian which is contained in the Sundanese vocabulary or Javanese vocabulary. In terms of the Indonesian language used as a communication tool tucked into the Sundanese vocabulary or Javanese vocabulary with the same form and meaning and used in a variety of appropriate languages, the possibility of communication will be fine. Indeed, many Sundanese and Javanese vocabularies are the same forms and different meaning, for examples

- 'bumi' in Sundanese mean 'rumah'. Its meaning not really close to the meaning of 'bumi' in Javanese. The word 'bumi' in Sundanese means 'rumah/house', a place where people need shelter, beside in Javanese 'bumi' means 'bumi/world'. Both are the same in concept namely a place.

- 'genep' in Sundanese means 'six' in numbers. Its meaning also different with 'genep' in Javanese. The word 'genep' in Javanese means 'not more and not less'.

- 'selapan', words with the same form and different meanings as in the word 'selapan' can cause misunderstandings when people with Sundanese cultural backgrounds with Javanese people communicate because the meaning of the word 'selapan' in Sundanese is very different when compared to the meaning of the word 'selapan' in Javanese, namely 'sembilang' and 'tiga puluh lima'. Both of them have meanings which related to numbers.

- 'gedang' in Sundanese is also very close to the meaning of 'gedhang' in Javanese. 'gedhang' in Javanese little bit 
BAHTERA: Jurnal Pendidikan Bahasa dan Sastra, Volume 18 Nomor 2 Juli 2019 http://journal.unj.ac.id/unj/index.php/bahtera/

P-ISSN : 0853-2710

E-ISSN : 2540-8968

different in form but the spelling is the same as 'gedang' in Sundanese. The word 'gedang' in Sundanese means 'papaya' while in Javanese it means 'pisang'. Both mean fruit names but different in characteristic of fruit.

- 'ical' in Sundanese means 'lost or sell' in numbers. Its meaning also different with 'genep' in Javanese. The word 'genep' in Javanese means 'not more and not less'. They are also the same in form but also different in meaning.

- 'alus' in Sundanese means 'good'. Its meaning different with 'alus' in Javanese. The word 'alus' in Javanese means 'smooth'. They are also the same in form but also different in meaning.

- 'cokot' in Sundanese means 'take', different with 'cokot' in Javanese which means 'bite'. They are the same in form but different in meaning.

- 'j(um)eneng' in Sundanese means 'alive'. Its meaning also different with 'jeneng' in Javanese. The word 'jeneng' in Javanese means 'stand'.

- 'lumpat' in Sundanese means 'run' whereas 'lumpat' means 'jump' in Javanese. The word 'lumpat' in Javanese and Sundanese are the same in form but different in meaning.

- 'rayi' in Sundanese means 'young brother/sister'. Its meaning also different with ' $r a i$ ' in Javanese. The word 'rai' in Javanese means 'face'. They are also the same in form but also different in meaning.
- 'tegalan' in Sundanese means 'land'. Its meaning also different with 'tegalan' in Javanese. The word 'tegalan' in Javanese means 'field'. They are also the same in form but also different in meaning.

- 'teh' in Sundanese means 'sister, another particle which mean 'sih' in Indonesian'. Its meaning is different with 'teh' in Javanese. The word 'teh' in Javanese means 'the name of the plant whose shoots are usually swayed and dried for drinks, it is one of the ingredients of tea'. Both words are same in form, different in meaning also their concept. One talks about human and the other about thing.

- 'urang' in Sundanese means 'me' in numbers. Its meaning also different with 'urang' in Javanese. The word 'urang' in Javanese means 'shrimp'. They are also the same in form but also different in meaning.

- 'waos' in Sundanese means 'teeth'. Its meaning also different with 'waos' in Javanese. The word 'waos' in Javanese means 'read'. They are also the same in form but also different in meaning.

- 'kasep' in Sundanese means 'handsome' in numbers. Its meaning also different with 'kasep' in Javanese. The word 'kasep' in Javanese means 'late'. They are also the same in form but also different in meaning.

Those Sundanese and Javanese words are the same in form and different in meaning. Only a word that is different in spelling, namely 'gedhang' in Javanese which is same in pronounciation. 
BAHTERA: Jurnal Pendidikan Bahasa dan Sastra, Volume 18 Nomor 2 Juli 2019 http://journal.unj.ac.id/unj/index.php/bahtera/

P-ISSN : 0853-2710

E-ISSN : 2540-8968

2) The same form and the same lexical meaning, different ways (in terms of familiar variety and respect/high)

\begin{tabular}{|c|c|c|c|c|}
\hline \multirow{2}{*}{ Indonesian } & \multicolumn{2}{|c|}{ Sundanese } & \multicolumn{2}{|c|}{ Javanese } \\
\hline & familiar variety & $\begin{array}{c}\text { respect/high } \\
\text { variety }\end{array}$ & familiar variety & $\begin{array}{c}\text { respect/high } \\
\text { variety }\end{array}$ \\
\hline bibir & biwir & Lambey & Lambe & lathi \\
\hline rambut & buuk & Rambut & Rambut & rikma \\
\hline kaki & suku & Sampéan & Sikil & suku/samparan \\
\hline malam & peuting & wengi & Wengi & dalu \\
\hline pulang & balik/mulang & wangsul mulih & balik/mulih & kundur \\
\hline berat & beurat & abot & abot & aorat \\
\hline makan & dahar & Tuang & mangan/madhang & dahar \\
\hline duduk & diuk & calik/linggih & linggih/lungguh & lenggah \\
\hline pakai & pake/make & Nganggo & Nganggo & ngagem \\
\hline pindah & Pindah & Ngalih & alih, elih, ngalih & pindah \\
\hline tidur & sare & kulem/bobo & Turu & sare \\
\hline
\end{tabular}

In conversation, a speaker must consider with whom he is talking to, where, about what, when, and in what condition. With these considerations there will be a variety of language uses in accordance with their functions and situations.
There are several words that should be think before using them to other people, specially to the older one in Sundanese and Javanese words. In Sundanese, bibir is 'biwir', rambut is 'buuk', kaki is 'suku', malam is 'peuting', pulang is 'baik/mulang', berat 
BAHTERA: Jurnal Pendidikan Bahasa dan Sastra, Volume 18 Nomor 2 Juli 2019 http://journal.unj.ac.id/unj/index.php/bahtera/

P-ISSN : 0853-2710

E-ISSN : 2540-8968

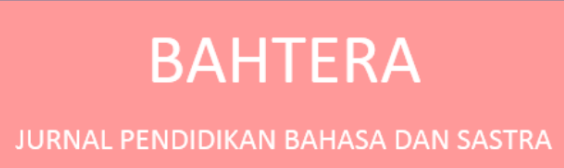

is 'beurat', makan is 'dahar', duduk is 'diuk', pakai is 'pake/make', pindah is 'pindah', and tidur is 'sare' in familiar variety. In Javanese, bibir is 'lambe', rambut is 'rambut', kaki is 'sikil', malam is 'wengi', pulang is 'balik/mulih', berat is 'abot', makan is 'mangan/madhang', duduk is 'linggih/lungguh', pakai is 'nganggo', pindah is 'alih/elih/ngalih', and tidur is 'turu'. Those are words in familiar variety. From the data can be seen that pulang means 'balik' that shows the same variety and form.

Beside respect/high variety, Sundanese and Javanese also have the same in form and meaning. In Sundanese, bibir is 'lambey', rambut is 'rambut', kaki is 'sampean', malam is 'wengi', pulang is 'wangsul mulih', berat is 'abot', makan is 'tuang', duduk is 'calik/linggih', pakai is 'nganggo', pindah is 'ngalih', and tidur is 'kulem/bobo'. In Javanese, respect/high variety can be seen from these words, namely bibir is 'lathi', rambut is 'rikma', kaki is 'suku/samparan', malam is 'dalu', pulang is 'kundur', berat is 'aorat', makan is 'dahar', duduk is 'lenggah', pakai is 'ngagem', pindah is 'pindah', dan tidur is 'sare'. Several words are the same with the familiar variety of Sundanese, such as in rambut, wengi, abot, dahar, linggih, nganggo, ngalih, pindah, dan sare. Those words are the same in form but different ini function.

It can be imagined when the vocabulary was pronounced but not according to whom someone who spoke to. However, there are some Sundanese vocabularies which belong to familiar variety, but it is also a variety of respect for the Javanese language, such as the words 'suku', 'dahar', and 'sare'. Similar

to Sundanese, if the vocabulary is misused, then it will occur misunderstanding.

\section{CONCLUSION}

Javanese and Sundanese are the major regional languages in Indonesia in terms of the number of speakers. Speakers of both languages are millions, while other regional languages have only thousands of speakers, some even hundreds. Many of the Sundanese and Javanese people met in the same place. Communication between Sundanese and Javanese can be in Indonesian which is contained in the Sundanese or Javanese vocabulary. In terms of the Indonesian language used as a communication tool that is contained in the vocabulary of the Sundanese language or the vocabulary of the Javanese language which has the same form and meaning and is used in a variety of appropriate languages, the possibility of communication will be fine.

Sundanese and Javanese form are the same, but the meaning is different. In addition, in both languages the same form is found, the lexical meaning is also the same, but its use in different languages. This causes misunderstanding. Thus, this research is expected to be used as a reference for speakers to be careful in communicating so that there will be no misunderstanding.

\section{REFERENCES}

Agustina, A. C. dan L. (2010). Sosiolinguistik: Perkenalan Awal (Revisi). Jakarta: Rineka Cipta.

Auliya Az Zahra, A. P. (2016). Pengaruh Cultural Barrier Terhadap

Komunikasi Lintas Budaya dan Stres 
BAHTERA: Jurnal Pendidikan Bahasa dan Sastra, Volume 18 Nomor 2 Juli 2019 http://journal.unj.ac.id/unj/index.php/bahtera/

P-ISSN : 0853-2710

E-ISSN : 2540-8968

Kerja Karyawan. Jurnal

Administrasi Bisnis (JAB)|Vol. 36

No. 1 Juli 2016|.

https://doi.org/10.1561/2200000016

Gunardi, D. (1996). Undak Usuk dan

Dampaknya dalam Perilaku Bahasa

Sunda. Jakarta: Pusat Pembinaan

dan Pengembangan Bahasa.

Kramsch, C. (2014). Language and

Culture, 27, 30-55.

https://doi.org/10.1075/aila.27.02kra

Lagu, M. (2016). e- journal "Acta

Diurna" Volume V. No.3. Tahun 2016. Komunikasi Antarbudaya Di Kalangan Mahasiswa Etnik Papua Dan Etnik Manado Di Universitas Sam Ratulangi Manado, V(3), 153166.

https://doi.org/10.3232/GCG.2015.V 9.N3.03

Nugroho, A. B., Lestari, P., \&

Wiendijarti, I. (2012). Pola

Komunikasi Antarbudaya Batak dan Jawa di Yogyakarta. Jurnal
Komunikasi, 1(5), 403-418.

Paramita, S., \& Sari, W. P. (2016).

Komunikasi Lintas Budaya dalam

Menjaga Kerukunan antara Umat

Beragama di Kampung Jaton

Minahasa Intercultural

Communication to Preserve

Harmony Between Religious Group

in Jaton Village Minahasa. Jurnal

Pekommas, 1(2), 153-166.

Rudianto, Syam, T., \& Harahap, M. S. (2015). Komunikasi Lintas Budaya Wisatawan Asing dan Penduduk Lokal di Bukit Lawang. Jurnal SImbolika, 1(September), 188-193.

Sudaryanto. (1993). Metode dan Aneka Teknik Analisis Bahasa. Yogyakarta: Duta Wacana University Press.

Suwito, P. D. (1990). Sosiolinguistik. Surakarta: Universitas Sebelas Maret.

Wedhawati, D. (2006). Tata Bahasa Jawa Mutkhir. Yogyakarta: Kanisius. 